\title{
Effects of Crude Alkaloids Isolated from Peganum harmala Seeds on the Growth and Metabolism of Leishmania tropica Promastigotes
}

\author{
Marua H. AL-Hammoshi \\ Department of Pharmacology \\ College of Pharmacy \\ Mosul University
}

(Received 7/4/2010; Accepted 20/9/2010)

\begin{abstract}
The present work aimed to examine the efficacy of Peganum harmala Linn. alkaloids as potential antilieshmanial agents in vitro, and to determine their toxicity in mice.

The study included extraction and isolation of Peganum harmala crude alkaloids from seeds. The isolated fraction that contains alkaloids was detected, using Myer`s and modified Dragendorff's reagents. Then, the crude alkaloids were tested for their antileishmanial activity against Leishmania tropica promastigotes in vitro including their effects on parasite growth and metabolism.

It was found that the studied alkaloids inhibited growth of the parasite remarkably. The inhibitory concentration of $50 \%$ of the promastigotes $\left(\mathrm{IC}_{50)}\right.$ at the log phase (96) hrs was $50 \mu \mathrm{g}$ of the alkaloids/ $\mathrm{ml}$ of culture.

Furthermore, the extracted alkaloidal fraction from Peganum harmala seeds, resulted in decline of RNA, DNA, and protein content of the parasite and reduced specific activity of dihydrofolate reductase and thymidine phosphorelase enzymes. It also had obvious inhibitory effects on energy metabolism of the parasite.

Oral median lethal dose (oral $\mathrm{LD}_{50}$ ) of the extracted alkaloids was $1070 \mathrm{mg} / \mathrm{kg}$ body weight in Balb/c mice, using the up-and-down method.

It can be concluded that Peganum harmala alkaloids show promising antilieshmaneal activity and may have potential role in the search for novel antilieshmaneal drugs, as they affect metabolism of proteins, nucleic acids and energy of the parasite (in vitro) with a slight toxicity in mice (in vivo).
\end{abstract}

Keywords: Lieshmania tropica, Peganum harmala, alkaloids, growth, carbohydrates, energy, fumarate reductase, succinate dehydrogenase, dihydrofolate reductase, thymedine phosphorelase, $\mathrm{LD}_{50}$. 


\section{تنأثير الفلوبدات الخلم المعزولة من بذور الحربل Peganum harmalaف نمو ولض Leishmania tropica أملي السطا للافيليلت اللثمانيا الجلية}

\section{الملخص - المص}

يهوف العهل الحالي إلى بيلن كفاءة قلويدات نبلت الحرل Peganum harmala (العائل ـة ال سسذابية) بوصفها مضادات لطفيلي اللثمانيا في الزجاج، مُ تحديسمية هذه القلويدات في الحيولنت المختبرية.

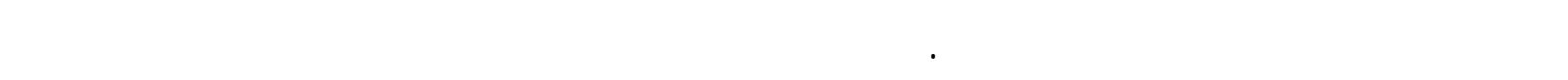

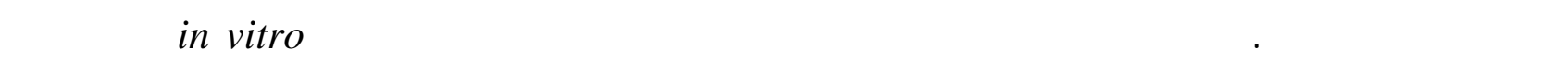

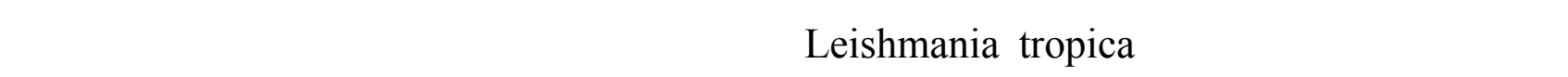
الطفيلي.

تبين أن القلويدات قيد الدرلسة أثرت عله نمو الطفيلي بشكل واضح، التركيز القانل ل50\% من أم لمي

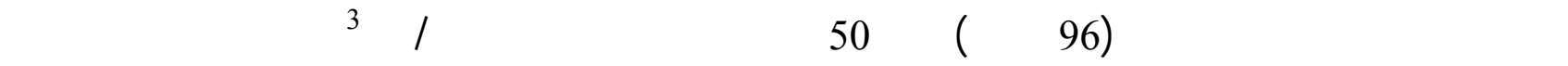



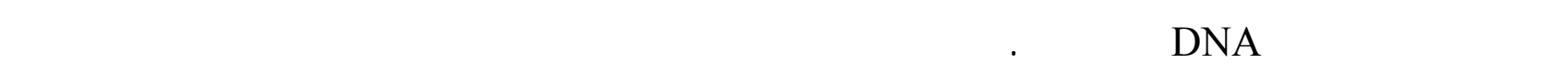
ركتيز وثايمدن فوسفورليز, فضلا عن تأثيرها التبطي الواضكح لأيض التين الطاقة في الطفيلي.

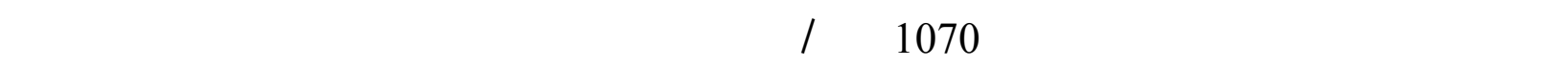
Balb/ c نخم بالقول أن قلويدات الحرهل أعطت فعالية واعة كمضادات الشمانيا، ويمكن العطل عليها كترلكي با


والطاقة الطفيلي في الزجاج معسمية قليلة في الحيوانات المختبرية.

الكاملت الدالة: اللثمانيا الجلية، الحرهل، قلويدات، نمو، كاربوهيدرات،طلة، فيوماريت ركتيز،سكسنيت

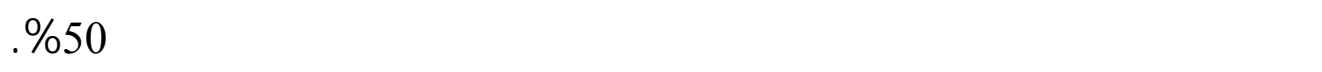

\section{INTRODUCTION}

Leishmaniasis is a global parasitic infection, which is prevalent in 88 countries from Tropical to Mediterranean regions, where 12 million people are infected and approximately 350 million people are at risk, with 1-2 million new cases registered annually (WHO,2001). It is a vector-borne disease transmitted by sand flies and caused by an obligate intracellular protozoa of the genus Leishmania. There are four major species of genus Leishmania, similar in morphology, but different in cultural characteristics, clinical manifestations, geographic distribution, and sand fly vectors, cause disease in humans. Leishmania tropica 
of Old World cutaneous leishmaniasis or oriental sore is prevalent in some of the MiddleEastern countries, Tropical Africa and in Asia (including Iraq) (WHO, 2002).

The drugs available for the treatment of leishmaniasis are, in general, toxic, expensive and require long-term treatment. Large-scale clinical resistance against the most commonly used antimonial agents, has been reported (Berman, 1997). Drug treatment of leishmaniasis is complicated by the variation in sensitivity of Leishmania species, the different disease manifestations, the lack of controlled clinical trails of new (and old) drugs for leishmaniasis and recently, the increasing levels of antimonial resistance (Croft, 2001). The spread of drug resistance, combined with other shortcomings of the available antilieshmanial drugs (Eibl, 2000), emphasize the importance of the development of new effective and safe drugs against leishmaniasis.

Alkaloids are a large group of compounds that occur throughout the plant kingdom, those have pharmacological important, quinolinic, isoquinolinic, steroidal and $\beta$-carboline alkaloids of plant source proved to have a significant antilieshmanial activity against Leishmania, in vitro and in vivo. (Chan-Bacab and Pena-Rodrigues, 2001). The plant Peganum harmala is a source of these compounds (Kamel et al., 1970).

Several different protozoan infections have been shown to be susceptible to Peganum harmala extracts in varying degrees, including Theileria spp., Babesia spp., Anaplasma cabali and Lieshmania donovani (Lala et al., 2004 ; Mirzaei, 2007). The present work is focused on isolation of crude alkaloids from the seeds of Peganum harmala Linn. to determine their toxicity in vivo and test their antimetabolic activity of Leishmania tropica promastigotes in vitro, in addition to their effects on protein, nucleic acids and energy metabolism in the parasite.

\section{MATERIALS AND METHODS}

\section{Isolation of Peganum harmala crude alkaloids}

Seeds of Peganum harmala were collected from local markets in Mosul city and taxonomically identified by the botanists Mr. Salim AL-Sufaji, in herbarium of Biology department /College of Science /University of Mosul. The seeds were milled into coarse powder, then extracted with ethanolic alcohol 80\% that contains diluted HCL (1N); pigments and unwanted materials were removed by shaking with chloroform. The free alkaloids were then precipitated by the addition of excess ammonia and separated by filtration (Evans, 1997). The extracted fraction which contains alkaloids was detected, using Myer's reagent (Potassiomercuric iodide solution) (Sousek et al., 1999) and modified Dragendorff's reagent (Potassium bismuth solution) (AL-Shahaat, 1986).

\section{Biological activity of the extracted seeds alkaloids in vitro}

\section{A. Leishmania used:}

MHOM / IQ / 1992 / MREC3 Leishmania tropica stock culture was used. The culture was obtained from the College of Medicine AL-Nahreen University, which has been characterized using isoenzyme method according to AL-Jeboori and Evans (1980). The obtained culture was cultivated in Tobie`s medium (Tobie et al., 1950). 


\section{B. Cultivation and estimating numbers of parasites:}

$1.9 \mathrm{ml}$ of liquid phase was added to McCantry vialscontaining $5 \mathrm{ml}$ solid phase slants, $0.1 \mathrm{ml}$ of Leishmania promastigotes inoculums was taken from stock culture during logarithmic phase, so that the initial density of the organism was $2 \times 10^{5} / \mathrm{ml}$, then the number of organisms of new culture incubated at $26 \mathrm{C}^{0}$ for 4 days, was counted directly using a haemocytometer.

\section{Effect of the extracted Peganum harmala seeds alkaloids on growth, generation number and generation time of Leishmania tropica promastigotes:}

Effect of the isolated alkaloids on growth was studied in vitro in comparison with untreated groups. The compound was dissolved in $2 \%$ dimethyl sulfoxide (DMSO). Six concentrations $(20,30,40,50,60,70) \mu \mathrm{g} / \mathrm{ml}$ were prepared to determine the $\mathrm{IC}_{50}$ and $\mathrm{IC}_{90}$ of the cultivated organisms. Numbers of promastigotes were determined at different time intervals $(24,48,72,96)$ hours, then generation number and time of each culture at each time interval was estimated using Benjamin and German laws (1993).

\section{D- Biochemical studies: \\ a- Estimation of total proteins, nucleic acids, and carbohydrates:}

Lowry et al., (1951) method was used for protein quantitative determination. While Schneider's method (1957) was used for quantitative estimation of total nuliec acids, DNA, and RNA. Herbert et al., (1971) method were carried out to estimate total carbohydrates in treated and untreated parasites.

\section{b-Enzyme studies:}

Determination of thymidine phosphorelase (TP) activity was carried out using an assay system, which has been adopted by AL-Janker (1999). Activities were measured by assaying one of the products, deoxyribose-1-phosphate, using the diphenylamine method (Burton, 1956). Specific activity of TP was expressed as the number of nanomoles of produced deoxyribose-1-phosphate. Absorbance was measured at $600 \mathrm{~nm}$ spectroscopically.

Dihydrofolate reductase (DHFR) activity was determined depending on assay system, which was illustrated by Baccnari et al., (1975) and adopted by Al-Chalabi and AL-Khayat (1986). Unit of enzyme activity was expressed as the amount of enzyme required for oxidation of $1 \mu \mathrm{M}$ of NADPH/minute of reaction depending on NADPH extinction coefficient $=6.2 \times 103 \mathrm{M}-1 \mathrm{~cm}-1$, Absorbance was measured at $340 \mathrm{~nm}$ (Mathews et al., 1963).

Succinate dehydrogenase (SDH) activity was determined using method adopted by Al-Hasany (2004). It depends on reduction of the co-enzyme, flavine adenine dinucleutide (FAD) To FADH2 by succinic acid (SA):

Succinic acid + SDH-FAD $\longleftrightarrow$ Fumaric acid +FADH2

Specific activity of succinate dehydrogenase $=$ number of FAD reduced nanomoles / minute/ mg protein, Absorbance measured at $720 \mathrm{~nm}$.

Activity of NADH-depending fumarate reductase(FRD- NADH) enzyme was assessed by a modified method originally described by Denicola-Seoane et al., (1992) and adopted by Chen et al., (2001). Unit of enzyme activity was expressed as the amount of enzyme required for oxidation of $1 \mu \mathrm{M}$ of $\mathrm{NADH} /$ minute of reaction depending on NADH extinction coefficient $=6.2 \times 10^{3} \mathrm{M}-1 \mathrm{~cm}^{-1}$ and absorbance of $340 \mathrm{~nm}$. 
Determination of the median lethal dose $\left(\mathrm{LD}_{50}\right)$ of the isolated crude alkaloids in mice

Oral medium lethal dose of Peganum harmala crude alkaloids in Balb/c mice were determined using up-and-down method (Dixon, 1980). Male mice aged $4-6$ weeks were injected with different doses of the isolated alkaloids. Primary dose $(500 \mathrm{mg} / \mathrm{kg}$ body weight) was chosen after conducting series of test levels.

Statistical analysis used in this study included: F-test using analysis of variance (ANOVA table) and Duncan's multiple range test and difference between two samples mean (t-test). The level of significance was $\mathrm{P} \leq 0.05$ (AL-Rawi and Kalaf-Allah, 1980 ; Daniel et al., 1983).

\section{RESULTS AND DISCUSSION}

Therapeutic evaluations for medicinal plants are essential because of the growing interests in alternative therapies and the use of natural products. Natural products have potential in the search for new and selective agents for the treatment of important tropical diseases caused by protozoans (Wright and Phillipson, 1990).

The pharmacologically active compounds of Peganum harmala are several alkaloids, which are found especially in the seeds and the roots. These include $\beta$-carbonile alkaloids such as harmine, harmaline, harmalol and harman, and quinazoline alkaloides such as vasicine and vasicinone (Kamel et al., 1970). Thus, In the present work, crude alkaloids of peganum harmala seeds where isolated in the form of brown colored sticky material. As shown from alkaloids detection, which was accomplished using Myer's test (Sousek et al., 1999) and modified Dragendorff's test (AL-Shahaat, 1986). Results were positive with both tests; I e. Production of creamy color precipitate and reddish-brown precipitate, respectively.

\section{Effect of isolated crude alkaloids on the growth, generation number and generation time of Leishmania tropica promastigotes in vitro:}

Crude alkaloids isolated from Peganum harmala seeds were tested for their antileishmanial properties in vitro. Table 1 shows the inhibitory effects of different concentrations of the crude alkaloids on Leishmania growth in comparison with control group, during different time intervals. Relatively all concentrations used demonstrated significant inhibitory effects against Leishmania promastigotes. An inverse relationship could be established between concentration of the alkaloids and growth mean of the parasite. Inhibitory concentration of $50 \%$ of promastigotes $\left(\mathrm{IC}_{50}\right)$ was $50 \mu \mathrm{g} / \mathrm{ml}$, where as $\mathrm{IC}_{90}$ was $70 \mu \mathrm{g} / \mathrm{ml}$ at logarithmic phase (96hrs. of cultivation).

On the light of the growth indices (Table 1), effect of the crude alkaloids on generation number and generation time of Leishmania tropica promastigotes were estimated (see paragraph $\mathrm{C}$ of materials and methods). As for the effect of different concentrations of the extracted alkaloids on generation number ( Table 2 ), inverse correlation between generation number and concentration were observed, generation number at log phase ranged from 6.18 generations at $20 \mu \mathrm{g}$ alkaloids / $\mathrm{ml}$ culture to 4.08 generations at $70 \mu \mathrm{g} / \mathrm{ml}$, when compared with control group (6.74 generations ).

However, generation time appeared to depend upon the concentration of the alkaloids (Table 3). Generation time increased when concentration increased (direct correlation). At 
$\log$ phase, generation time values ranged from $15.53 \mathrm{hrs}$. at $20 \mu \mathrm{g} / \mathrm{ml}$ to $19.35 \mathrm{hrs}$. at $70 \mu \mathrm{g}$ / ml when compared with control group (14.24) hrs.

The significant inhibitory effect of Peganum harmala alkaloids on the growth of Leishmania tropica promastigotes may be elucidated by different reasons. Mirzaie (2007) pointed out that the $\mathrm{IC}_{50}$ of Peganum harmala acidic extract was $1832.65 \mu \mathrm{g} / \mathrm{ml}$ of Lieshmania major growth. Lala et al., (2004) estimated that the death of Leishmania donovani promastigotes that were pretreated with harmine alkaloids could be attributed to cell necrosis due to non-specific membrane damage. On the other hand, Li et al., (2007) revealed that, some beta-carboline alkaloids, including some Peganum harmala alkaloids, are specific inhibitors of cyclin dependent kinases (CDKs). Therefore, to give a picture on the mode of action of Peganum harmala alkaloids, as antilieshmaneal agents at molecular level, further investigation applied using biochemical tests in the next part of the research is required.

Table 1: Effect of different concentrations of the isolated alkaloids on numbers of Leishmania tropica promastigotes at different time intervals.

\begin{tabular}{|c|c|c|c|c|c|c|c|c|}
\hline \multirow{2}{*}{$\begin{array}{l}\text { Exposure } \\
\text { time (hrs }\end{array}$} & \multirow{2}{*}{$\begin{array}{c}24 \\
\text { Mean }^{*} \\
\pm \mathrm{SE}\end{array}$} & \multirow{2}{*}{ ১゚ } & \multirow{2}{*}{$\frac{48}{\operatorname{Mean}_{\text {SE }}^{*} \pm}$} & \multirow{2}{*}{ ○。 } & \multirow{2}{*}{$\begin{array}{c}72 \\
\text { Mean }^{*} \\
\pm \mathrm{SE}\end{array}$} & \multirow{2}{*}{ ه゚ } & 96 & \multirow{2}{*}{ ه゚ } \\
\hline & & & & & & & $\operatorname{Mean}^{*} \pm \mathrm{SE}$ & \\
\hline Control & $\begin{array}{c}14.67^{ \pm} \\
0.26^{\mathrm{d}}\end{array}$ & -- & $\begin{array}{c}29.50 \pm \\
1.60^{\mathbf{e}} \\
\end{array}$ & -- & $\begin{array}{c}122.00 \pm \\
3.33^{\mathrm{f}}\end{array}$ & -- & $210.33 \pm 6.39^{\mathbf{e}}$ & 0 \\
\hline 20 & $\begin{array}{c}11.00 \pm \\
0.76 \mathrm{c}\end{array}$ & 25 & $\begin{array}{c}25.00 \pm \\
2.08 \mathrm{~d}\end{array}$ & 15 & $\begin{array}{c}86.50 \pm \\
5.31 \mathrm{e}\end{array}$ & 29 & $143 . .02 \pm 4.28 \mathrm{~d}$ & 32 \\
\hline 30 & $\begin{array}{l}9.17 \pm \\
0.44 \mathrm{~b}\end{array}$ & 38 & $\begin{array}{c}22.00 \pm \\
1.52 \mathrm{c}\end{array}$ & 25 & $\begin{array}{c}76.86 \pm \\
0.23 \mathrm{~d}\end{array}$ & 37 & $136.71 \pm 0.04 \mathrm{~d}$ & 35 \\
\hline 40 & $\begin{array}{c}8.17 \pm \\
0.44 \mathrm{bc}\end{array}$ & 44 & $\begin{array}{c}20.67 \pm \\
0.93 \mathrm{c}\end{array}$ & 30 & $\begin{array}{c}73.67 \pm \\
0.75 \mathrm{~d}\end{array}$ & 40 & $118.50 \pm 4.07 \mathrm{c}$ & 41 \\
\hline 50 & $\begin{array}{l}7.17 \pm \\
0.60 \mathrm{~b}\end{array}$ & 51 & $\begin{array}{c}14.83 \pm \\
0.72 \mathrm{~b}\end{array}$ & 50 & $\begin{array}{c}59.33 \pm \\
2.44 \mathrm{c}\end{array}$ & 51 & $102.33 \pm 2.80 b$ & 49 \\
\hline 60 & $\begin{array}{c}4.00 \pm \\
0.29 \mathrm{a}\end{array}$ & 73 & $\begin{array}{l}9.50 \pm \\
0.30 \mathrm{a}\end{array}$ & 68 & $\begin{array}{c}26.33 \pm \\
0.73 \mathrm{~b}\end{array}$ & 78 & $50.83 \pm 2.20 \mathrm{a}$ & 75 \\
\hline 70 & $\begin{array}{c}2.67 \pm \\
0.33 \mathrm{a} \\
\end{array}$ & 81 & $\begin{array}{c}9.00 \pm \\
0.03 \mathrm{a} \\
\end{array}$ & 69 & $\begin{array}{c}11.33 \pm \\
0.60 \mathrm{a}\end{array}$ & 91 & $33.50 \pm 2.84 \mathrm{a}$ & 83 \\
\hline
\end{tabular}

* Three replicates were used for each treatment. Mean and Standard Error were multiplied x $10^{5}$.

$* *$ Initial number of promastigotes used in each culture $=2 \times 10^{5}$.

*** Different letters refers to presence of significant differences between treatments at $\mathrm{P} \leq$ 0.05 , according to Duncan's test. 
Table 2: Effect of different concentrations of the isolated alkaloids on generation number of Leishmania tropica promastigotes at different time intervals.

\begin{tabular}{|c|c|c|c|c|}
\hline $\begin{array}{c}\text { Exposure } \\
\text { time (hrs.) }\end{array}$ & 24 & 48 & 72 & 96 \\
\hline$(\mu \mathrm{g} / \mathrm{ml})$ & Mean $^{*} \pm$ SE & Mean $^{*} \pm$ SE & Mean $^{*} \pm$ SE & Mean $^{*} \pm$ SE \\
\hline Control & $2.9 \pm 0.04^{\mathbf{e}}$ & $3.90 \pm 0.26^{d}$ & $5.95 \pm 1.50^{\mathrm{e}}$ & $6.74 \pm 0.11^{d}$ \\
\hline 20 & $2.47 \pm 0.09^{\mathrm{de}}$ & $3.66 \pm 0.00^{\mathrm{cd}}$ & $5.45 \pm 0.22^{d}$ & $6.18 \pm 0.12^{c}$ \\
\hline 30 & $2.2 \pm 0.00^{d}$ & $3.47 \pm 0.06^{\mathbf{c}}$ & $5.28 \pm 0.11^{\mathrm{d}}$ & $6.11 \pm 0.003^{c}$ \\
\hline 40 & $2.04 \pm 0.02^{d}$ & $3.38 \pm 0.05^{c}$ & $5.22 \pm 0.23^{d}$ & $5.91 \pm 0.46^{b}$ \\
\hline 50 & $1.85 \pm 0.01^{\mathbf{c}}$ & $2.90 \pm 0.16^{b}$ & $4.91 \pm 0.04^{\mathbf{c}}$ & $5.70 \pm 0.60^{b}$ \\
\hline 60 & $1.01 \pm 0.01^{b}$ & $2.26 \pm 0.05^{\mathrm{a}}$ & $3.73 \pm 0.01^{b}$ & $4.96 \pm 0.03^{a}$ \\
\hline 70 & $0.42 \pm 0.01^{\mathrm{a}}$ & $2.18 \pm 0.01^{\mathrm{a}}$ & $2.51 \pm 0.01^{\mathrm{a}}$ & $4.08 \pm 0.02^{\mathrm{a}}$ \\
\hline
\end{tabular}

Table 3: Effect of different concentrations of the isolated alkaloids on generation time (hours) of Leishmania tropica promastigotes at different time intervals.

\begin{tabular}{|c|c|c|c|c|}
\hline $\begin{array}{l}\text { Exposure } \\
\text { time (hrs.) }\end{array}$ & 24 & 48 & 72 & 96 \\
\hline $\begin{array}{l}\text { Treatments } \\
(\mu \mathrm{g} / \mathrm{ml})\end{array}$ & Mean $^{*} \pm$ SE & Mean $^{*} \pm$ SE & Mean $^{*} \pm$ SE & Mean $^{*} \pm$ SE \\
\hline Control & $8.28 \pm 0.82^{\mathrm{a}}$ & $12.30 \pm 0.31^{\mathrm{a}}$ & $12.10 \pm 0.04^{\mathrm{a}}$ & $14.24 \pm 0.17^{\mathrm{a}}$ \\
\hline 20 & $9.72 \pm 2.11^{\mathbf{b}}$ & $13.11 \pm 0.00^{b}$ & $13.21 \pm 0.90^{b}$ & $15.53 \pm 0.19^{b}$ \\
\hline 30 & $10.91 \pm 0.00^{\mathrm{c}}$ & $13.83 \pm 0.81^{b c}$ & $13.64 \pm 0.83^{\mathrm{c}}$ & $15.71 \pm 0.01^{\mathbf{b}}$ \\
\hline 40 & $11.76 \pm 1.84^{\mathrm{d}}$ & $14.20 \pm 0.60^{c}$ & $13.79 \pm 1.22^{\mathrm{c}}$ & $16.24 \pm 1.33^{\mathrm{cd}}$ \\
\hline 50 & $12.97 \pm 2.35^{\mathrm{e}}$ & $16.55 \pm 0.28^{d}$ & $14.66 \pm 0.15^{d}$ & $16.84 \pm 1.88^{\mathrm{d}}$ \\
\hline 60 & $23.76 \pm 4.36^{f}$ & $21.24 \pm 1.73^{\mathrm{e}}$ & $19.30 \pm 0.11^{\mathbf{e}}$ & $19.35 \pm 1.89^{\mathrm{e}}$ \\
\hline 70 & $57.14 \pm 2.02^{\mathrm{g}}$ & $22.02 \pm 1.08^{f}$ & $19.30 \pm 0.11^{\mathrm{f}}$ & $19.35 \pm 1.89^{f}$ \\
\hline
\end{tabular}

\section{2 - Biochemical studies:}

\section{I - Effect of $\mathrm{IC}_{50}$ of Peganum harmala crude alkaloids on total protein, nucleic acids} content and some related enzymes of Leishmania promastegotes in vitro:

Peganum harmala alkaloids found to cause significant reduction in protein, DNA and RNA content in Leishmania tropica promastigotes that were treated with $\mathrm{IC}_{50}$ of the tested alkaloids (Table 4), the higher reduction caused by these alkaloids was obsereved on the percentage concentration of DNA $(41.82 \%)$. In the present work, and on the light of efficacy of Peganum harmala alkaloids as protein and nucleic acids metabolic inhibitors, the specific activity of thymidine phosphorelase (TP) and dihydrofolate reductase (DHFR) of the treated parasites were estimated. The isolated alkaloids found to reduce $42.59 \%$ of thymidine phosphorelase (TP) specific activity and $26.23 \%$ of dihydrofolate reductase (DHFR) specific activity (Table 5). Furthermore, it should be taken into account that particular antiparasitic agent may affect metabolism of protein when affects nucleic acids metabolism of the parasite.

Proteins of protozoan cells have similar characters of those in higher organism (Bryent and Behm, 1989). Many antiprotozoan agents affect metabolism of proteins and nucleic 
acids of the target organism like ketokonazole, allopurinol, chloropromazine, ethidium, dihudroemitine and soramine (Hassan, 1979 ; AL-Healy, 2000), and different modes of action suggested for antilieshmanial drugs as protein and nucleic acids metabolic inhibitors (Hassan, 1979; Chang et al., 1985; AL-Chalabi, 1986 ; AL-Jebouri, 2002).

On the other hand, beta-carboline alkaloids present in medicinal plants, such as Peganum harmala and Eurycoma longifolia, have recently drawn attention due to their antitumor activities. Further mechanistic studies indicate that beta-carboline derivatives inhibit DNA topoisomerases in yeast and then interfere with DNA synthesis ( $\mathrm{Li}$ et al., 2007). Besides, peganine hydrochloride dehydrate (isolated from Peganum harmala seeds) found to inhibit DNA topoisomerase, thus interfere with DNA synthesis in Lieshmania donovani promastigotes and amastigote (Misra et al., 2008). Li et al., (2007) revealed that, some beta-carboline alkaloids (such as Peganum harmala alkaloids) are specific inhibitors of cyclin dependent kinesis (CDKs). They concluded that the antitumor activity of betacarboline drugs could be attributable to their inhibition of CDK.

Because thymidine nucleotides are important precursors for DNA synthesis, a number of enzymes involved in its metabolism has been investigated in Leishmania. In addition, Leishmania and Trypanosoma lack a significant salvage pathway for dTMP (Hassan, 1979). These properties have important implications for rational chemotherapy of leishmaniasis, and since in many cells; any strategy aimed at dTMP deprivation would require the simultaneous blockage of both de novo and salvage anabolic pathways. Therefore, effects of the isolated alkaloids on the activity of DHFR and TP were taken into account to point out the possible mechanism of action of these alkaloids as nucleic acids and polypeptides synthesis inhibitors in leishmania parasite.

Results illustrated in Table (5) showed that the tested alkaloids had significant effects on dTMP synthesis, since they affect activity of DHFR, a key enzyme in the synthesis of thymidylate by de novo pathway, and therefore of DNA(Chang et al., 1985). On the other hand, they showed significant inhibitory effects on TP activity, the important enzyme in the synthesis of dTMP by salvage pathway in Leishmania promastigotes (Chang et al., 1985), i.e. the former results indicated that the tested alkaloids had relatively significant inhibitory effects on both de novo and salvage pathways in the parasite. These results reflected in a way the high inhibitory effects of these alkaloids on DNA synthesis, i.e. DNA content (see Table 4). AL-Chalabi (1986) demonstrated that treating Leishmania tropica promastigotes with $10-4 \mathrm{~mol} / \mathrm{ml}$ of paramomycine sulfate inhibited $50 \%$ of thymidylate syanthetase activity; he concluded that this effect may result in interaction with DNA synthesis.

DHFR inhibitors have been used in chemotherapy of malaria for nearly 40 years (Fernando and Dolores, 2001). It is also a potential target for developing drugs against leishmania species and trypanosomes (Zuccotto et al., 1998). The bases of the antiinfective selectivity of folate antagonists, like trimethoprim and pyrimethamine and methotrexate, are potent inhibitors of bacteria and protozoal DHFRs. These species of selective agents apparently exploit the differences in the active site regions of the parasite and host enzymes (Schweitzer et al., 1990). AL-Khayat (1981) found that treating Leishmania donovani and Leishamnai tropica promastigotes with aminoptirine and methotrexate reduced $50 \%$ of DHFR activity; she also found that some antifolate compounds like methotrexate have high affinity to compete with folate and inhibit DHFR activity; as a result, they inhibit the synthesis of dTMP. 
Furthermore, some plant extracts that contain alkaloids have been found to have inhibitory effects on dTMP metabolism, for example, AL-Khan (2001), revealed that aqueous extract of Capparis spinosa increased activity of Leishmania major TP about $20.6 \%$, and decreased thymidylate syanthetase activity of the same parasite about $17.6 \%$. He concluded that salvage pathway takes the place of de novo pathway and this and this explain the increase of TP activity in opposite to decrease of thymidylate syanthetase activity.

AL-Jubouri (2005) revealed that treating Leishmania tropica promastigotes with $\mathrm{IC}_{50}$ of Nirium oleander extract reduced $73 \%$ of DHFR activity. AL-Fahhady (2006) demonstrated that treating Leishmania tropica promastigotes with $\mathrm{IC}_{50}$ of a Urtica piluifera reduced $28.9 \%$ of DHFR activity. It could be concluded that dTMP is apossible site of action for the isolated alkaloids as antilieshmanial agents.

\section{II- Effect of $\mathrm{IC}_{50}$ of Peganum harmala crude alkaloids on energy metabolism (carbohydrate content and some related enzymes) of Leishmania promastegotes in vitro:}

Table 6 shows that there is an increase in glucose $(\mathrm{CHO})$ content in parasites those treated with $\mathrm{IC}_{50}$ of the tested alkaloids when compared with control group. As its known, carbohydrates are important source of energy in living organisms including parasites (Bryant and Behm, 1989), i.e. carbohydrates residue (17.94\%) in treated parasite may indicate energy metabolism defect. Thus, specific activity of two enzymes (succinate dehydrogenase and NADH depending fumarate reductase) was reported in respiratory chain of Leishmania parasite (Hellemond and Tielens, 1997).

Table 7 shows that the tested alkaloids decrease significantly both the specific activity of fumarate reductase and succinate dehydrogenase, thus affect cellular respiration in the parasite. This result somewhat explains the accumulation of glucose in treated parasites. Thus, the two mitochondrial enzymes, FRD-NADH and SDH, of Leishmania tropica promastigotes were proved to be the site of action of the isolated alkaloids, i.e. they are involved in the inhibition of parasites energy metabolism, and, since, the inhibitory effect of the experimented alkaloids against parasite SDH activity was $11 \%$ higher than that on inhibitory effect of these alkaloids against FRD-NADH activity (Table 7), leishmania SDH is more sensitive to the tested alkaloids than FRD-NADH. These data my indicate the inhibitory effects of these alkaloids on respiratory enzyme (energy metabolism ) of both mammalian host and the parasitic cells. This result may refer to the possible toxicity of Peganum harmala alkaloids to mammalian animals.

Some well-known antiprotozoal drugs and some potential antiprotozoal compounds influence the energy metabolism of leishmania, like pentamidine isothionate core, sodium stibogluconate (Berman et al., 1989) and mycotoxin MT 81 (Majumdar et al., 1993). Misraei (2007) Found that the alkaloid compound vasicine (peganine) had significant antileishmanial activity against promastigote stage of Leishmania donovani. Which induce apoptosis in L. donovani amastigote and promastigotes via loss of mitochondrial transmembrane potential.

As it is known, biological system of energy metabolism is essential for the survival, continued growth and reproduction of the living organisms. Typical mitochondria are usually considered to be oxygen-consuming, ATP-producing organelles. They use pyruvate 
dehydrogenase for oxidative decarboxilation of pyruvate to acetyl coenzyme $\mathrm{A}$, which is then completely oxidized to $\mathrm{CO}_{2}$ through the Krebs cycle. (Champ et al., 2005).

In parasitic organisms, the carbohydrate and energy metabolism differ greatly from those of their vertebrate hosts. The most important factors in this respect are the nutrient and oxygen supply (Bryant and Behm, 1989). For example leishmania promastigotes depend mainly on respiratory chain activity for energy generation, have a poor capacity for anaerobic functioning, and go into a reversible metabolic arrest during anoxia, which enables them to survive anoxia for at least 48 hours (Santhamma and Bhaduri, 1995). Hellemond and Tielens (1997) demonstrated that respiratory chain inhibition or anoxia in Leishmania infantum promastigotes resulted in a strong inhibition of motility, proliferation, glucose catabolism, in addition to succinate production. This shows that succinate production does not occur via fumarate reduction and cannot be used as electron-sink. The same researchers concluded that leishmania promastigotes lack a true fermentative energy metabolism, in contrast to insect stages of other kinetoplastidae, like Trypanosomes.

FRD catalyzes the reduction of fumarate to succinate, which is a key enzyme in anaerobic energy metabolism for many organisms respiring with fumarate as a terminal electron acceptor. This enzyme has been found among some bacteria such as Helicobacter pylori and Escherichia coli (Iverson et al., 1999), and among protozoal parasites of the genera trypanosoma, plasmodium, and leishmania (see Santhamm and Bhaduri, 1995 ), and in helminths (Bryant and Behm, 1989).

Fumarate-NADH reductase is obligatory component of the respiratory chain of Leishmania parasite, which was shown to be totally absent in mammalian host (Santhamma and Bhaduri, 1995). Because of that, FRD-NADH has been used specially as a target of leishmaniasis treatment by some researchers (Kharmazmi et al., 1997). In the present work, effect of the Peganum harmala alkaloids on specific activity of promastigotes succinate dehydrogenase was also investigated on FRD-like enzymes in mammalian cells. SDH plays a very important role in the respiratory chains of both mammalian cells and leishmania cell, as one of the classical electron transport enzymes. SDH also conducts the reverse reaction to that which FRD conducts (Hellemond and Tielens, 1997).

In eukaryotes and prokaryotes, aerobically respirated:

Succinic acid + SDH-FAD $\longleftrightarrow$ Fumaric acid +FADH2

In low eukaryotes and prokaryotes under anoxia conditiones:

Fumaric acid +FRD-NADH $\longrightarrow$ Succinic acid + NAD $+2 \mathrm{H}$

The two proteins, FRD-NADH and SDH exhibit substantial similarities in amino acid sequence, cofactor composition, and mechanism. Indeed, under certain conditions, one enzyme can functionally replace the other and support organism growth (Pealing et al., 1992). Because of the central role of fumarate reductase and succinate dehydrogenase in respiration, mutations in this complex can have substantial metabolic consequences. In bacteria, mutations in fumarate reductase can significantly retard growth under appropriate conditions. In higher organisms, mutations of succinate dehydrogenase have been linked to oxidative stress (Iverson et al., 1999). In the present work, the effect of Peganum harmala alkaloids had no selective effect on Leishmania FRD-NADH, thus, this enzyme could not be considered as a target site of antileishmanial activity of these alkaloids. 
Table 4: Effect of $\mathrm{IC}_{50}(50 \mu \mathrm{g} / \mathrm{ml})$ of Peganum harmala alkaloids on the amount of total protein $(\mu \mathrm{g} / \mathrm{ml})$ and total nucleic acids $(\mu \mathrm{g} / \mathrm{ml})$ at log-phase $(96 \mathrm{hrs})$.

\begin{tabular}{|c|c|c|c|}
\hline Macromolecule type & $\begin{array}{c}\text { Macromolecule } \\
\text { content } \\
\mu \mathrm{g} / \mathrm{ml} \mathrm{Mean}^{*} \pm \mathrm{SE} \text {. }\end{array}$ & \%Macromolecule & \%reduction \\
\hline $\begin{array}{l}\text { Protein: } \\
\text { Control }\end{array}$ & $556.20 \pm 8.9$ & 100 & 0 \\
\hline$\mu \mathrm{g} / \mathrm{ml}$ & $422.22 \pm 5.1$ & 75.91 & 24.09 \\
\hline $\begin{array}{l}\text { Total nucleic acids } \\
\text { Control }\end{array}$ & $121.55 \pm 0.95$ & 100 & 0 \\
\hline$\mu \mathrm{g} / \mathrm{ml}$ & $91.07 \pm 1.2$ & 74.92 & 25.08 \\
\hline $\begin{array}{l}\text { DNA: } \\
\text { Control }\end{array}$ & $28.55 \pm 0.86$ & 100 & 0 \\
\hline$\mu \mathrm{g} / \mathrm{ml}$ & $16.61 \pm 0.35$ & 58.17 & 41.82 \\
\hline $\begin{array}{l}\text { RNA: } \\
\text { Control }\end{array}$ & $93.81 \pm 1.2$ & 100 & 0 \\
\hline$\mu \mathrm{g} / \mathrm{ml}$ & $73.77 \pm 0.89$ & 78.64 & 21.36 \\
\hline
\end{tabular}

Table 5: Effects of $\mathrm{IC}_{50}(50 \mu \mathrm{g} / \mathrm{ml})$ of Peganum harmala alkaloids on the specific activity of Thymidine phosphorelase (TP) and dihydrofolatereductase (DHFR) at log-phase (96 hrs).

\begin{tabular}{|l|c|c|c|}
\hline \multicolumn{1}{|c|}{ Enzyme } & $\begin{array}{c}\text { Specific activity** } \\
\text { Mean* } \pm \text { SE. }\end{array}$ & \%Specific activity & \%Decrease \\
\hline $\begin{array}{l}\text { DHFR: } \\
- \text { Control }\end{array}$ & $179.92 \pm 1.5$ & 100 & 0 \\
\hline$-50 \mu \mathrm{g} / \mathrm{ml}$ & $132.72 \pm 1.3$ & 73.77 & 26.23 \\
\hline $\begin{array}{l}\text { TP: } \\
- \text { Control }\end{array}$ & $19.63 \pm 0.39$ & 100 & 0 \\
\hline$-50 \mu \mathrm{g} / \mathrm{ml}$ & $11.27 \pm 0.61$ & 57.41 & 42.59 \\
\hline
\end{tabular}

Table 6: Effect of $\mathrm{IC}_{50}(50 \mu \mathrm{g} / \mathrm{ml})$ of Peganum harmala alkaloids on the amount of carbohydrate content $(\mu \mathrm{g} / \mathrm{ml})$ at log-phase $(96 \mathrm{hrs})$.

\begin{tabular}{|c|c|c|c|}
\hline Treatment & $\begin{array}{c}\text { Glucose content } \\
\mathbf{\mu g} / \mathbf{m l} \\
\text { Mean* } \pm \text { SE. }\end{array}$ & \%Glucose & \%Residue \\
\hline Control & $97.10 \pm 3.8$ & 100 & 0 \\
\hline $50 \mu \mathrm{g} / \mathrm{ml}$ of the alkaloid & $114.52 \pm 2.2$ & 117.94 & 17.94 \\
\hline
\end{tabular}


Table 7: effects of $\mathrm{IC}_{50}(50 \mu \mathrm{g} / \mathrm{ml})$ of Peganum harmala alkaloids on the specific activity of Leishmania FRD-NADH and SDH at log-phase (96 hrs).

\begin{tabular}{|cc|c|c|c|}
\hline \multicolumn{2}{|c|}{ Enzyme } & $\begin{array}{c}\text { Specific activity** } \\
\text { Mean* } \pm \text { SE. }\end{array}$ & \%Specific activity & \%Decrease \\
\hline FRD: & Control & $328.40 \pm 0.88$ & 100 & 0 \\
\hline & $50 \mu \mathrm{g} / \mathrm{ml}$ & $320.36 \pm 1.1$ & 97.55 & 2.45 \\
\hline SDH: & Control & $284.05 \pm 4.0$ & 100 & 0 \\
\hline & $50 \mu \mathrm{g} / \mathrm{ml}$ & $244.43 \pm 1.5$ & 86.05 & 13.95 \\
\hline
\end{tabular}

\section{3- Determination of $\mathbf{L D}_{50}$ in Balb/c mice}

In vitro antilieshmanial activity of Peganum harmala alkaloids was encouraging and prompted us to confirm the toxicity in vivo, in mice models. Quintal dose-response used extensively to evaluate toxicity of new chemicals or compounds in vivo (Doull et al., 1986). In the present research, oral $\mathrm{LD}_{50}$ was determined as a first attempt to evaluate toxicity of the alkaloids applying the up-and-down method (Dixon, 1980). According to toxicity rating chart (Depass, 1989) the tested alkaloids were considered to be slightly toxic for mice (1070 $\mathrm{mg} / \mathrm{kg}$ body wight) (Table 8 ). Survived mice at sublethal doses $(500$ and $1000 \mathrm{mg} / \mathrm{kg}$ body weight) showed lethargy and prostration, lose of appetite, trembling, walking difficulties and some times, loss of consciousness before recovery or died.

Table 8: Estimated oral $\mathrm{LD}_{50}$ of the extracted alkaloids in Balb/c mice.

\begin{tabular}{|c|c|}
\hline Measurements & Values \\
\hline Median lethal dose $(\mathrm{mg} / \mathrm{kg}$ ) body weight & 1070 \\
\hline Upper and lower doses $(\mathrm{mg} / \mathrm{kg})$ body weight & $500-3000$ \\
\hline Number of mice used & 7 \\
\hline Result after 24 hrs. & OOO OXXO \\
\hline Final dose $(\mathrm{mg} / \mathrm{kg}$ )body weight & 1500 \\
\hline
\end{tabular}

X: death O: survival

While this plant has traditionally been used in Bedouin medicine as an emmenagogue and as abortifacient agent (Casey, 1960), there are few reports on its human toxic effects and syndrome (Salah et al., 1986).All parts of Peganum harmala plant are thought to be toxic. Domestic animals are susceptible to poisoning from this plant, and camels are the most often affected (El-Bahri and Chemli, 1991). Bellil (1983) referred to the digestive and nervous syndromes in animals that consume a sub-lethal amount of the plant. He also illustrated that these animals initially become prostrate and then anorexia, hypersalivation, vomiting and diarrhea occur; in addition to excitability that was followed by trembling, stiffness and accelerated breathing. In Merck Index, Intravenous lethal dose fifty $\left(\mathrm{LD}_{50}\right.$-iv) 
of harmine alkaloid that is isolated from Peganum harmala seeds is $38 \mathrm{mg} / \mathrm{kg}$ in mice, while subcutaneous lethal dose fifty $\left(\mathrm{LD}_{50}-\mathrm{Sc}\right)$ is $200 \mathrm{mg} / \mathrm{kg}$ in rats (Budavari and O 'Neil, 1996).

On the other hand, Puzii and Serov (1983) revealed that the extract of Peganum harmala is a natural drug, which does not infiltrate in muscles of cattle. Mirzaei (2007) pointed out the therapeutic effects of $P$. harmala extract for the treatment of tropical theileriosis in cattle. i.e. $P$. harmala extract has a significant antitheilerial activity on Thyleria annulata (protozoan parasite) in vivo. Lala et al., (2004) demonstrated that the alkaloid harmine found in Peganum harmala, proved to have appreciable efficacy in destroying the intracellular parasite (lieshmania amstigotes) as well as non-hepatoxic and non-nephrotoxic nature for human. They concluded that harmine, in the vesicular forms, may be considered for clinical application in humans.

Present study concludes that Peganum harmala alkaloids show a promising in vitro antilieshmanial activity with slight toxicity in vivo and can be considered as new lead structures in the search for novel antilieshmanial drug. Therefore, there is a need for further investigation about the efficacy of Peganum harmala alkaloids as antilieshmaneal agents in vivo (in animals) to determine therapeutic indices of such compounds.

\section{ACKNOWLEDGMENT}

Researcher wants to present her deepest appreciation to Dr. Wafaa Mohammed Ali Hamed, Assistant professor in Pharmacognacy/ College of Pharmacy/ Mosul Univ. for her valuable advice throughout conducting the work. Deepest thanks go also to Mr. Salim ALSufaji/ Lecturer/Biology Dept./ College of Science/Mosul Univ. for his help in classification of the plant.

\section{REFERENCES}

AL-Chalabi, K. A. (1986). Effect of paramomycin sulfate on growth and thymine nucleotide metabolism in Leishmania tropica promastigotes. Proc. of the 4th Sceint. Conf., Sci. Res. Counc., Baghdad, Oct. 23-28, 5(1), 230-236.

AL-Chalabi, K. A. ; AL-Khayat, B. H. (1986). Properties of dihydrofolate reductase from Leishmania donovani and Leishmania tropica promastigotes. JBSR., 17(2), $107-$ 117.

AL-Fahhady, BK. (2006). Effect of some medical herbs on growth and metabolism of different clinical parasitic groups in Iraq. Ph.D. Thesis, College of Education, Tikrit University, Iraq.

AL-Hasany, A. M. (2004). Study the electrochemical behaviour of coenzyme flavine adinine dinucleotide (FAD) and estimation the activity of succinate dehydrogenase enzyme (SDH). M.Sc. Thesis, Collage of Sciences, Mosul University, Iraq.

AL-Healy, H. L. (2000). Effect of chloropromazine on growth and metabolism on promastigote forms of Leishmania parasite. M.Sc. Tesis, College of Science, Mosul University.

AL-Janker, M. H. (1999). The molecular effect of cadmium, copper and zinc on the growth and metabolism of free living Tetrahymena pyriformis (Ehrenberg, 1830). Ph.D. Thesis, College of Science, Mosul University, Iraq. 
AL-Jeboori, T. I. ; Evans, D. A. (1980). Leishmania spp. In Iraq. Electrophoretic isoenzyme pattern II. Cuteneous leishmaniasis. Trans. Roy. Soc.Trop. Med. Hyg., 74, 178-184.

AL-Jebouri, N.S. (2002). Study of the effect of purine analoges on growth and metabolism of Leishmania major promastigotes. Msc. Thesis, College of Education, University of Tikrit, Iraq.

AL-Jubouri, S. A. (2005). Effect of aqueous extracts of Nerium oleander and Metia azedarach on growth and metabolism of Leishmania tropica promastigotes in vitro. M.Sc. Thesis, College of Science, Mosul University, Iraq.

AL-Khan, H. J. (2001). Effect of aqueous extracts of Capparis spinosa and Citrullus colocynthis plants on growth and metabolism of Leishmania major promastigotes in vitro. Ph.D. Thesis, College of Science, Mosul University, Iraq.

Al-Khayat, B.H. (1981). Studies on some aspects of pyrimidine cnucleotide metabolism of Iraqi species of Leishmania. M. Sc. Thesis, College of Science, University of Mosul, Iraq.

AL-Rawi, K. ; Kalaf Allah, A. M. (1980). The Completely Randomized Design, in: "Design and Analysis of Agricultural experiments". House of Books for printing and publication, Mosul, pp.37-94.

AL-Shahaat, N. (1986). "Plants and Medicinal Herbs". Dar AL-Bahaar, Beirut, pp. 140-146.

Baccanari, D.; Phillps, A. ; Smith, S.; Sinki, D. ; Burchalls, J. (1975). Purification and properties of E. coli dihydrofolate reductase. Biochemistry., 14, 5267-5277.

Bellil, H. (1983). Les intoxication d vegetate Chez le dromadaire dans le sud tunisien. These Doct. Vet., 1, 66-72.

Benjamin, C. L. ; German, G. R. (1993). "Students Study Guide Microbiology". Concepts and application. McGrow-Hill. Book Company. pp. 254-248.

Berman, J. D.; Edwards, M.K. ; Grogl, M. (1989). Biochemistry of pentostam resistant Leishmania. Am. J. Trop. Med. Hyg., 40, 159-164.

Berman, J.D. (1997). Human leishmaniasis: clinical, diagnostic, and chemotherapeutic developments in the last 10 years. Clin. Infect. Dis., 24, 684-703.

Bryant, C. ; Behm, C. (1989). "Biochemical Adaptation in Parasites", Energy metabolism, Chapman and Hall, London, UK. pp.25-69.

Budavari, S. ; O'Neil, MJ. (1996). The Merck Index. 12th edn. CRC press, Peganum harmala: 4644-4645.

Burton, K. (1956). A study of conditions and mechanisms of the diphenylamine reaction for colorimetric estimation of deoxyribonucleic acid. Biochem. J., 63, 315-323.

Casey, RC. (1960). Alleged antifertility plants of India. Indian J. Med Sci, 14, 590-600.

Champ, PC.; Harvey, RA. ; Ferrier, DR. (2005). "Lippincotts Illustrated Reviews: Biochemestry". 3rd edn. Lippincot Williams and Wilkins, USA. pp. 378-381.

Chan-Bacab, M. J. ; Pena-Rodriguiz, L. M. (2001). Plant natural products with Leishmanicidal activity. Nat. Prod. Rep., 18, 674-688.

Chang, KP.; Fong, D. ; Bray, RS. (1985). "Biology of Leishmania and Leishmaniasis" Elsevier Science Publishers, B.V. (Biomedical division). USA. pp.166-173.

Chen, M. ; Zhai, L.; Christensen, S. B.; Theander, T. G. ; Kharazmi, A. (2001). Inhibition of fumarate reductase in Leihmania major and Leishmania donovani by chalcons. Antimicrob. Agents. Chemother., 45(7), 2023-2029. 
Croft, S. L. (2001). Monitoring of drug resistance in leishmaniasis. Tropical Medicine and International Health., 6 (II), 899-905.

Daneil, W. W. (1983). "Biostatistics. A Foundation for Analysis in the Helth Science". 3rd edn. John Wiley and Sonns. New Yourk. pp. 87-89.

Denicola-Seoane, A.; Rubbo, H. ; Prodanov, E. ; Turrens, JF. (1992). Succinate-depending metabolism in Trypanosoma cruzi epimastigotes. Mol. Biochem. Parasitol., 54, 4350 .

Depass, L.R.(1989). Alternative approaches in median lethality (LD50) and acute toxicity testing. Toxicol. Lett., 49, 159-170.

Dixon, W.J. (1980). Efficient analysis of experimental observations. Ann. Rev. Toxicol. , 20, 441-462.

Doull, J.; Klassen, C. D. ; Amdur, M. O. (1986). "Casarett and Doull`s Toxicology". The basic science of poisons. 3rd ed. Macmillan publishing Company. Inc. Toronto. pp.25-38.

Eibl, H. (2000). "Cure for Fatal Tropical Disease-Oral Treatment of Leishmaniasis". Max Planck Institute for Biophysical Chemistry, UK.

EL-Bahri, L ; Chemli, R. (1991). Peganum harmala L: Poisonous plant of North Africa. Vet. Hum. Toxicol. 33, 276-277.

Evans, WC. (1997). "Treaus and Evans Pharmacognosy". 4th edn. W. B. Saunders Company limited, V. P. India: pp.340-408.

Fernando, HZ. ; Dolores, GP. (2001).Tryponosomal dUTPases as potential targets for drug design. Current protein and peptide scence., 2, 389-397.

Hassan, H.F. (1979). Studeis on thymidine nucleotide metabolism in Leishmania. MSc. Thesis, College of Science, Mosul Unive Iraq.

Hellemond, V.J. ; Tielens, AG. (1997). Leishmania promastigotes have a poor capacity for anaerobic functioning, depend on respiration for their energy generation and inhibition of respiration .-induces a metabolia arrest that enables them to survive anoxic conditions First world congress on leishmaniasis abstracts. Acat Parasitologica Turcica. 21(1), 142.

Herbert, D.; Philips, P. J. ; Stance, R. E. (1971). "In Methods in Microbiology". (5B). (Ed. Norris) J.R. and Ribbons D. W. Academic Press. London and New York. pp.241245.

Iverson, TM.; Luna, CC.; Chccini, G. ; Ress, DC. (1999). Structure of Escherichia coli fumarate reductase respiratory complex.. Science., 284, 1961-1966.

Kamel, S.; Ibrahim, L.; Afifi, A. ; Hamza, S. (1970). Alkaloidal constituents of the Egyptian plant. Peganum Harmala. UARJ, Vet Sci., 7, 71-86.

Kharmazmi, A.; Chen, M.; Zhia, L. Nielsen, SF. ; Christensen, SH. (1997). Discovery and development of oxygenated chalcones A5 potential novel antileishmanial agents. First world congress on leishmaniasis abstracts. Acat Parasitologica Turcica. 21 (1), 371.

Lala, S.; Pramanick, S.; Mukhopadhyay, S.; Bandyopadhyay, S. ; Basu, MK. (2004). Harmine: evaluation of its antileishmanial properties in various vesicular delivery systems. Journal of Drug Targeting. 12 (3), 165-75. 
Li Y.; Liang, F.; Jiang, W.; Yu, F.; Cao, R.; Ma, Q.; Dai, X. ; Jiang, J. ; Wang, Y. ; Si, S. (2007). DH334, a beta-carboline Anti-Cancer Drug, Inhibits the CDK Activity of Budding Yeast. Cancer Biol Ther. 6(8), 17-19.

Lowry, O. H.; Rosebrough, N. J.; Farr, A. L. ; Randall, R. J. (1951). Protein measurement with the Folin-phenol reagent. J. Biol. Chem., 193, 265-275.

Majumdar, U. K.; Gupta,M.; Chowdhury, S. ; Saha, A.K. (1993). Antileishmanial activities of mycotoxine MT 81 and its derivatives. Indian J. Exp. Biol., 31, 888-890.

Mathews, C.K.; Scrimgeour, K. G. ; Huennekens, F. M. (1963). Dihydrofolic acid reductase. Eds,: Colowick, S. P. and Kaplau, N.O. " Methods in enzymology". 1,364-368.

Mirzaei, M. (2007). Treatment of natural tropical theileriosis with the extract of the plant Peganum harmala. Korean J. Parasitol., 45(4), 267-271.

Misra, P.; Khaliq, T.; Dixit, A.; Sen Gupta, S.; Samant, M.; Kumar, A.; Kshawaha, PK.; Majumdar, HH.; Saxena, AK.; Narender, t.; Dube, A. (2008). Antileishmanial activity mediated by apoptosis and structure-based target study of peganine hydrochloride dehydrate: An approach for rational drug design. J. antimichrobial Chemotherapy. 62(5), 998-1002.

Pealing, S. L.; Black, A.A.; Manon, F. D.; Ward, F. B.; Chpman, S. K. ; Reid, G. A, (1992). Biochemistry., 31, 12132-12140.

Puzii, A. D. ; Serov, V. M. (1983). Persistence of pegarmin (apreparation of the alkaloids of Peganum harmala in the body of cattle). Veterinaria. 5, 62-64.

Salah, NB. ; Amamou, M.; Jerbi, Z.; Salah, FB. ; Yacoub, M. (1986). Un cas de surdosage en Peganum harmala L. J. Toxicol. Clin. Exp, 6, 319-322.

Santhamma, KR. ; Bhaduri, A. (1995). Characterization of respiratory chain of Leishmania donovani promastigotes. Mol. Biochem. Parasitol., 75, 43-53.

Schneider, W. C. (1957). Determination of nucleic acids in tissues by pentose analysis in: " Methods in Enzymology". Vol. 111, Academic Press. New York. pp.515-517.

Schweitzer, BI.; Dicker, AP. ; Bertino, JR. (1990). Dihdrfolate reductase as a therapeutic target. The FASEB J., 4, 2441-2452.

Sousek, J.; Guedon, D.; Adam, T.; Bochorakova, H.; Taborska, E.; Valka, I. ; Simanek, V. (1999). Alkaloids and organic acid content of eight Fumaria species. Phytochemical Analysis, 10, 6-11.

Tobie, E. J. ; Brand, T. V. ; Mehlman, B. (1950). Cultural and physiological observations on Trypanosoma rhodesiense and Trypanosoma gambiense. J. Parasitol., 36, 48-54.

WHO (2001). World Health Organization Division of Control of Parasitic Diseases. Geneva, Switzerland.

WHO. (2002). Leishmaniasis. World Health Organization. Geneva, Switzerland.

Wright, CW. ; Phillipson, JD. (1990). Natural products and the development of selective antiprotozoal drugs. Phytother. Res.; 4, 127-139.

Zuccotto, F.; Zvelebil, M.; Lakowski, R.A. Thornton, J.M. ; Gilber, I.H. (1998). Dihydrofolate reductase as a potential target in Trypanosomes and Leishmania. $J$. Comput-Aided Mol. Des., 12, 241-257. 